\title{
THE BYZANTINE HOSPITAL ORGANIZATION AND THE KNIGHTS OF ST JOHN IN JERUSALEM
}

\author{
ESTEBAN GREIF \\ Consejo Nacional de Investigaciones Científicas y Técnicas \\ Universidad de Buenos Aires \\ Argentina
}

Date of receipt: $29^{\text {th }}$ of November, 2018

Date of acceptance: $11^{\text {th }}$ of June, 2019

\begin{abstract}
Towards the second half of the $12^{\text {st }}$ century, the order of the Hospitallers in the Latin Kingdom of Jerusalem finished the construction of the great hospital that granted it the high degree of recognition and prestige in the medieval world. Within the set of the studies which attended the medical work of the order, the diet imposed to the patients of the domus Dei has been a subject used to indicate the origin of the medical knowledge and the therapeutically organization adopted by the Hospitallers. In this way, the similarities between the allowed foods and those prohibited in different medical treatises that circulated in the medieval world, with those that the Hospital assigned in his palace to the sick have been pointed out. In this work we consider the problems that arise from this kind of interpretations and we indicate an alternative interpretation about the origin of the hospital model adopted by the order.
\end{abstract}

\section{KeYWORDS}

Hospital of Saint John, Circulation of knowledge, Hospital diet, Hospital model, Latin Kingdom of Jerusalem.

\section{Capitalia verba}

Hospitale Sancti Iohannis, Circulatio scientiae, Diaeta hospitalis, Exemplum hospitalium, Regnum Latinum Hierusalem. 


\section{The hospital in Jerusalem: towards the origin of a therapeutic and organizational hospital model}

The first studies on the medical practice developed in the Latin Kingdom of Jerusalem and the institutions dedicated to caring for the sick during the era of the crusades, date from the second half of the $20^{\text {th }}$ century. In the beginning, this tradition of studies had a slow growth. ${ }^{1}$ Regarding the institutions that offered some kind of medical attention, these studies focused mainly in the place of the Knights of St John and their medical work in the Hospital in Jerusalem and Acre. ${ }^{2}$ On the set of these works was established the background for the most important studies from the last 25 years regarding the medical developments in the crusaders states. ${ }^{3}$

One of the aspects of this tradition of studies was the analysis of the circulation of knowledge and medical practices developed in the Frankish states. In this sense, the Hospital of St. John was one of the institutions that received more attention among the historians. The main question was about the source and provenance of the medical ideas on which the Hospitallers based the therapies disposed in their domus Dei. In this sense, the diet prescribed on patients has been a subject used by different authors to indicate the origin of the therapeutical model in this institution. Namely, a method based in the search for coincidences between the foods prescribed in various medical treatises circulating in the medieval world with those that the Order of St. John assigned in its house for the sick. In this regard, the first work was from Indrikis Sterns. The author noted that the medical treatment and the diet prescriptions of the military orders in Outremer were inspired in the teachings of the School of Salerno. In his work, he compared the dietary prescriptions in the Regimen

1. Wickersheimer, Ernst. “Organisation et législation sanitaires au royaume franc de Jerusalem (10991296)". Archives internationales d'histoire des sciences, 16 (1951): 689-705. Woodings, Anne. F. "The medical resources and practice of the Crusader States in Syria and Palestine, 1096-1193". Medical history. 15 (1971): 268-277.

2. To mention only some of these studies: Delaville-Le Roulx, Joseph. Les Hospitaliers en Terre Sainte et à Chypre, 1100-1310. Paris: E. Leroux, 1904; Hume, Edgard, E. Medical work of the Knights Hospitallers of Saint John of Jerusalem. Baltimore: Johns Hopkins Press, 1940. About the medical practice of the rest of the military orders during the crusades in Outremer see: Mitchell, Piers D. "The infirmaries of the Order of the Temple in the medieval kingdom of Jerusalem", The Medieval Hospital and Medical Practice, Barbara S. Bowers, ed. London: Ashgate, 2007: 225-234.

3. Some of the most prominent contributions are, Sterns, Indrikis. "Care of the sick brothers by the crusader orders in the Holy Land". Bulletin of the History of Medicine, 57 (1983): 43-69; Edgington, Susan. "Medical knowledge in the Crusading armies: the evidence of Albert of Aachen and others", The Military Orders: fighting for the faith and caring for the sick, Malcolm Barber, ed. London: Ashgate, 1994; Kedar, Benjamin, ed. "A twelfth-century description of the Jerusalem Hospital", The Military Orders: fighting for the faith and caring for the sick, Helen J. Nicholson, ed. London: Ashgate, 1998: II, 3-26; Edgington, Susan. "Oriental and occidental medicine in the crusader states" The Crusades and the Near East: Cultural Histories, Conor Kostick, ed. London: Routledge, 2011 . The important book of Piers Mitchell: Mitchell, Piers. D. Medicine in the Crusades, warfare, wounds and the medieval surgeon. Cambridge: Cambridge University press, 2004. Regarding the circulation of medical ideas and hospital models between Europe and the East Mediterranean see, Bridgman, Robert Frederic. "Evolution comparée de l'organisation hospitalière en Europe et en Pays d'Islam", Atti del I Congresso Europeo di Storia Ospitaliera (Reggio Emilia 6-12, giugno 1960). Reggio Emilia: Centro Italiano di Storia Ospitaliera, 1962: 229-239. 
sanitatis salernitanum ${ }^{4}$ with those indicated in the statutes of the different military orders. Therefore, between these and the Italian school, Sterns noted numerous similarities in the indication of meals and therapies. ${ }^{5}$

Susan Edgington and Piers Mitchell repeated the same procedure some years after. They indicated the coincidence points between the statutes of the Hospitallers with diet prescriptions in other medieval medical treatises. Unlike Sterns, they did not focus on texts of European provenance, but in those from the East. In this way, for Edgington, the physicians in the Hospital of Saint John based their work on the teachings from the Arabian texts, which circulated in the West thanks to the translations made in the School of Salerno. In particular, she highlighted the importance of the medical treatise written by al-Majusi ( $i$ ? - ca. 994), named kitab al-malaki (Book of the Medical art), in the training of the doctors that would have attended in the palace of Jerusalem. ${ }^{6}$ Mitchell, ${ }^{7}$ on the other hand, founded more similarities between the diet indicated in the medical treatise of Oribasius of Pergamum (320-400), titled "Diet for the emperor"8 and the foods prescribed in the statutes of the Hospitallers. ${ }^{9}$

In this work, we will point out some of the difficulties of this kind of readings and a different interpretation about the origin of the medical organization of the great hospital in Jerusalem. We will indicate these difficulties out from the analysis of the different sources that inform us about the diet imposed by the order of St. John to his patients. In our proposal, the focus of the comparison will fall, not on the most influential medical treatises, but on the medical institutions developed in the byzantine world. We will compare the information of the domus Dei in Jerusalem with the administrative regulations -typika - of the hospitals associated with the monasteries of Pantokrator ${ }^{10}$ and the Kosmosoteira. ${ }^{11}$

4. Regimen Sanitatis Salernitanum. The School of Salernum, ed. John Harington. New York: Paul B. Hoeber, 1920 .

5. Sterns, Indrikis. "Care of the sick brothers...": 54-55.

6. Edgington, Susan. "Medical care in the Hospital of St John in Jerusalem", The Military Orders: fighting for the faith and caring for the sick, Helen Nicholson, ed. London: Ashgate, 1998: II, 30-31.

7. Mitchell, Piers. D. Medicine in the Crusades...: 99-103.

8. Grant, Mark, ed. Dieting for an Emperor: a Translation of Books 1 and 4 of Oribasius Medical Compilations with an Introduction and Commentary. Leiden - New York: Brill, 1997.

9. Delaville-Le Roulx, Joseph, ed. Cartulaire Général de l'Ordre des Hospitaliers de S. Jean de Jerusalem. Paris: Académie Royale des inscriptions et belle-lettres, 1895-1906: IV, 339-340 (doc. No. 494); IV 429-435 (doc. No. 627).

10. Gautier, Paul. "Le typikon du Christ Sauveur Pantocrator". Revue des études byzantines, 32 (1974): 1-145. English translation: Jordan, Robert, trans. “Typikon of Emperor John II Komnenos for the Monastery of Christ Pantokrator in Constantinople", Byzantine monastic foundation documents: a complete translation of the surviving founders' typika and testaments, eds. John Thomas, Angela Constantinides Hero. Washington: Dumbarton Oaks studies, 2000: II, 725-781.

11. Petit, Louis. "Typikon du monastère de la Kosmosotira, près d'Ænos (1152)". Izvêstija Russkago archeolog, instituta $v$ Konstantinopolê, 13 (1908): 17-77. English translation: Patterson Sevcenko, Nancy, trans. “'Kosmosoteira: Typikon' of the 'Sebastokrator' Isaac Komnenos for the Monastery of the Mother of God 'Kosmosoteira' near Bera", Byzantine monastic foundation documents: a complete translation of the 


\section{The Hospital diet: problems of interpretation}

Why can we affirm the comparison between the medieval medical treatises with the regulations established by the Hospitallers in Jerusalem regarding the medical treatment of the sick are not a viable procedure to set the origin of a particular hospital model? In the first place, because these are texts with different orientations and meanings. Therefore, a comparison between them is meaningless. In this sense, the diet prescribed in the statutes of the Knights Hospitallers falls outside of a "strictly" medical criterion. The liturgical hours of every day or the particulars meals for different religious festivities had an enormous influence in the foods and drinks which could be (or not) supplied to the sick and also to all the residents into the complex of the Hospital. Indeed, as indicated in the document of the Administrative Regulations $^{12}$ of the hospital,

En karehme ont les malades peisson fres .iii. fois la semaine se len en puet trover ausi com il ont char en charnage, et a la fyee salei quant len ne puet torver fres. Es autres .iiii. jors il ont double cuisinat amandelei ou trie, ou ris aveuc chichres et raizins secs ou autre fruit. ${ }^{13}$

In the same way, the document established for "the four moments" the patient should receive double food ration. ${ }^{14}$

Es jors des granz gehunes sicome sont li .iiii. tens et autres granz gehunes aient li malade double cuisinat. Amandelei ou trie ou ris aveuc les chichres et pitance general de fruit se len en treuve a plantei. Es simples jors de venredi quant li fruit sont fres sovent aient pitance general. ${ }^{15}$

surviving founders' typika and testaments, eds. John Thomas, Angela Constantinides Hero. Washington: Dumbarton Oaks studies, 2000: II, 782-858.

12. This document belongs to the Codex Vat. Lat. 4852. It holds a series of regulations of the Hospitallers not included in the Delaville-Le Roulx, Joseph, ed. Cartulaire Général... They were wrote in some moment between the years 1177 and 1183 . They have information regarding the alimentation of the sick, on doctors and the hospital organization in general. Susan Edgington made the edition of this document: Edgington, Susan. "Administrative Regulations for the Hospital of St John in Jerusalem dating from the 1180s". Crusades, Benjamin Kedar, Jonathan Phillips, Michael Evans, Jonathan Riley-Smith, eds. London: Routledge, 2005: IV, 21-37. On the original manuscript and the edition criteria, see the introduction of the author: Edgington, Susan. "Administrative Regulations...": 21-22.

13. "In Lent the patients have fresh fish 3 times a week if it can be found, as well as having meat on meat (days), and as a general rule salted when one cannot find it fresh. On the other 4 days they have double rations of cooked food, almonds or choice food or rice with chickpeas and raisins or other fruit". Edgington, Susan. "Administrative Regulations...": 32.

14. Four groups of three days (always Wednesday, Friday and Saturday) of prayer and fasting. They take place after Pentecost, the first Sunday of Lent, the feast of Saint Lucia and the Feast of the Holy Cross.

15. "On the days of great fasts such as Ember days and other great fasts the patients have double rations of cooked food. Almonds or choice food or rice with chickpeas and the normal portion of fruit if it is to be found on the plants. On simple Fridays when the fruits are fresh they may often have the general serving". Edgington, Susan. "Administrative Regulations...": 30. 
As we can see, this criterion of food assignment was not according to known theories and therapies, but to the fasting days after the most important celebrations of the Latin Church.

The second element, which allows us to affirm the problem on comparing the diet prescriptions of the Hospital of Saint John with the dietary indications on different medical treatises of the time, derived from the fact that the theoretical-practical heritage of both western and eastern doctors during the Middle Ages was essentially the same: the Hippocratic-Galenic medicine. Thus, the meaning of a comparison on medical models coming from different spaces, -i.e. the Byzantine or the Persian world - as producers of different kinds of medical theory is meaningless. In this sense, if we expand, in a comparison like this, the sample of medieval authors, we could find major similarities in the dietary prescription between their medical treatises and the statutes of the Military orders. Indeed, the same Piers Mitchell pointed out that the same quantity of coincidences between the statutes of the Hospitallers with the text of Oribasius existed also with the book called Glossary of drug names of Maimonides (1135-1204) ${ }^{16}$ and other eastern medical treatises. ${ }^{17}$

In the same way, if the Hippocratic-Galenic theory had essentially the same theoretical basis of the medicine in the medieval world, we can assume that it was on this general basis that the military orders organized the rhythms and indications about the schedule of the meals, the type of food and its administration. For example, as we can see in the next passage on the Testimony of the Anonymous Cleric ${ }^{18}$ regarding the medical work of the Hospital of Saint John, the dietary prescription served as therapy to compensate the internal imbalances (sickness) that a person could suffer: Eorundem aliis alia sunt nociva, ideo illis plura offeruntur, ut unius pregustati nocumentum alterius subinducti vel adnichilare satagat vel temperare remedium. ${ }^{19}$

About a therapeutics based on the Hippocratic principles, a few lines after the Anonymous Cleric explained how the Hospital hired doctors to prescribe the proper diets. In this way, those doctors were responsible for indicating the food (...) ne curabiles egritudines per continuata similia vel nociva contraria fientur incurabiles, et sic fomenta languoris aut causas mortis eger reperiter in illis, que sue speraret effectiva salutis. ${ }^{20}$

Then, as we can see, it was about healing patients by the restitution of the internal balance of theirs organisms. We know that all therapy in the medieval world, both from

16. Meyerhof, Max, ed. Šarh asmā' al-'uqqār: un glossaire de Matière Médicale composé par Maïmonide: L'Explication des noms de drogues. Cairo: Imprimerie de l'Institut Français d'Archéologie Orientale, 1940.

17. Mitchell, Piers. D. Medicine in the Crusades...: 101.

18. The Latin text of the Anonymous Cleric belongs to the Ms. Munich Stadts bibliothek Clm 4620. It ocuppies the folia $132 \mathrm{v}$ a $139 \mathrm{v}$. The Ms. Manuscript is dated in the thirteenth century and it is the only copy that is preserved. There are two editions. The first, made by Benjamin Kedar. The second —with the French translation-, by Alain Beltjens. Respectively, Kedar, Benjamin, ed. "A twelfth-century description...". Beltjens, Alain, ed. "Le récit d'une journée au Grand Hôpital de Saint-Jean de Jérusalem sous le règne des derniers rois latins ayant résidé à Jérusalem ou le témoignage d'un clerc anonyme conservé dans le manuscrit Clm. 4620 de Munich". Société de l'Histoire et du Patrimoine de l'Ordre de Malte, 14 (2004). In our work, we compare both editions.

19. Beltjens, Alain, ed. "Le récit d'une journée...": 44.

20. Beltjens, Alain, ed. "Le récit d'une journée...": 45. 
the West and the East, started from the basic conception of the four humors and pairs of qualities assigned to each of these humors. Therefore, it is not a trustable method pointing out which model adopted the Hospitallers according to the coincidences between different medical treatises and the food medical indications.

In the same way, we could ask ourselves if the Knights of St John for the composition of theirs statutes took elements from different treatises and not only from those on which the historians founded more similarities. We know that both, the salernitanian text and the Oribasius' circulated in different formats among others since the late antiquity in all the Mediterranean area. Therefore, nothing would stop the study on more than one particular text. In the same way, the theoretical influence and the quotations between them were common. For example, the Regimen Sanitatis Salernitanum was product of different fragments from the $12^{\text {th }}$ and $13^{\text {th }}$ centuries taken from many translations of Arabic texts.

In this sense, the third problem of these studies comes from the temporal distance between the analyzed documents. The original document of al-Majusi would be from some moment of the last third of the tenth century, while the Oribasius', from the fourth century. The statues of the Hospitallers regarding the type of alimentation for the sick are from the end of the $12^{\text {th }}$ century (1182). Therefore, the temporal distance is, in one case about two centuries. In the other case, about eight centuries. Thus, the contaminations and corruptions that the originals of theses treatises of al-Majusi and Oribasius, would suffer from different copies and successive compilations on which they were included, should alert us on the value of the comparisons made by Mitchell and others.

Likewise, the date of the composition of the Regimen salernitanum, is unknown. Its final production could be from some moment between the eleventh and the thirteenth centuries. ${ }^{21}$ Thereby, its composition could be contemporaneous to the redaction of the statutes or, on the contrary, later to it and therefore unknown by the Hospitallers. If the last was the case, the Regimen salernitanum would have no influence neither in the composition of the statutes nor in other documents of the same years like the Administrative Regulations, which also bring us information about the medical prescriptions regarding the diet for the sick. ${ }^{22}$

Hence, considering the difficulties in comparing the diet in the hospital in Jerusalem with different medical treatises, in our analysis proposal we will compare different aspects of the organization of the great hospital of Saint John - built during the 50 's of the $12^{\text {th }}$ century-, with the byzantine medical culture of the time. We will analyze the documents attached to the domus Dei of Jerusalem, paying attention to the common points with the byzantine hospital organization ${ }^{23}$, in relation to the layout of

21. Beltjens, Alain, ed. "Le récit d’une journée...": 99.

22. Beltjens, Alain, ed. "Le récit d'une journée...": 99.

23. On byzantine hospitals see, Miller, Timothy. The birth of the hospital in the Byzantine Empire. Baltimore -London: The John Hopkins University press, 1997; Also, Miller, Timothy. "Byzantine hospitals". Dumbarton Oaks Papers, 38 (1984): 53-63. See also: Nutton, Vivian. "The Birth of the Hospital in the Byzantine Empire by Timothy S. Miller. Essay Review". Medical History, 30/2 (1986): 218-221. Also Horden, Peregrine. "The Earliest Hospitals in Byzantium, Western Europe, and Islam". The Journal of 
the wards, the professional hierarchy, the division of medical works and the patients attended. For this, we will compare the regulation documents of the hospitals attached to the great byzantine monasteries, i.e., The Mother of God Kosmosoteira - close to the city of Bera in the area of Thrace- and the Monastery of Christ Pantokrator in Constantinople, with the documents of the hierosolimitan institution.

\section{Byzantine hospitals and the Hospital of Saint John: compared models}

The composition of the administrative rule and the building of the monastery The Mother of God Kosmosoteira, belongs to Isaac Comnenos (1093- after 1152), towards the year $1152 .{ }^{24}$ The building of the monastery Christ Pantokrator and the composition of its rule belongs to the Emperor John Comneno II (1118-1143). ${ }^{25}$ Each of these rules has different sections about the hospital service and organization given to the brothers of the monastery, but also to the general population. The decision of comparing the information provided by these rules comes, in the first place, from the fact that this rules are from two monumental monasteries and their hospitals of great magnitude and therefore, similar to the Hospital of Saint John in Jerusalem. In the second place, the date of building of the Hospital of Saint John is contemporaneous with the date of building of the Pantokrator (1136) and practically simultaneous to the Kosmosoteira (after 1152). In the third place, there are historical factors that link the origin and the deployment of the order to Byzantium: the most important, the amalfitanian origin of the brethren that will later constitute the order of the Hospital, factor that allowed these brothers be in contact with the byzantine medical culture.

Indeed, the amalfitanians, who kept a close link with some byzantine monasteries in the Holy Land ${ }^{26}$ founded the first hospice on which the Order of Saint John arose in Jerusalem. ${ }^{27}$ The history of the Order began in the year 1071, when a group of

Interdisciplinary History, 35/3 (2005): 388-389; Horden, Peregrine. “How Medicalised Were Byzantine Hospitals?". Medicina $\theta$ Storia, 5/10 (2005): 45-74. Of the same autor, see also Horden, Peregrine. "The Byzantine welfare state: image and reality". The Society for the Social History of Medicine Bulletin, 37 (1985): 7-10.

24. On the building of the monastery, the composition of the typikon and other aspects regarding the life of the author, see the introduction to the work of Patterson Sevcenko, Nancy, trans. "Kosmosoteira: Typikon'...": 782-783.

25. See Jordan, Robert, trans. "Typikon of Emperor John II Komnenos...": 725-726. Regarding the hospital of the Pantokrator, see the classic work of Codellas, Pan S. "The Pantocrator, the Imperial Byzantine Medical Center of XIIth Century A.D. in Constantinople". Bulletin of the History of Medicine, 12/2 (1942): 392-410. Also, Kislinger, Ewald. “Der Pantokrator Xenon, ein trügerisches ideal?”. Jahrbuch der Österreichischen Byzantinistik, 37 (1987): 173-179.

26. Janin, Raymond. La Géographie Ecclésiastique de L'empire Byzantin. Paris: Institut français d'études byzantines, 1969: III, 570.

27. Amalfi, after Venice, was the city of the West, which hold majors economical and religious contacts with Byzantium. Miller, Timothy. "The Knights of St John and the hospitals of the Latin West". Speculum, 
merchants from Amalfi rebuilt the Benedictine monastery of Santa Maria of the Latins ${ }^{28}$ next to the hospice associated in Jerusalem. The hospice in question dated from the fifth century and was originally build by the Byzantines. After its renovation, the amalfitanians employed a group of Italian Benedictine brothers for the management of the complex. ${ }^{29}$ In a few years these brothers established a truly and efficient service of hospital attention and initiated a process of transformation that would make them to become one of the most powerful religious orders in the Latin East. ${ }^{30}$

At the same time, we need to consider also the importance of Amalfi in the origin of the Hospital due to the political links that existed between some important amalfitanian families and the maintenance and contributions made by these to religious houses in the Holy Land. ${ }^{31}$ By this way, like Timothy Miller declare, the amalfitanians were in contact with the orthodox monasticism. ${ }^{32}$ Therefore, it would not be striking that the Greek monastic tradition could model the creation of the first hospice what would then be the Order of the Hospital.

On the other hand, the fact that even during the Muslim domination philantropic institutions for the sick existed attached to byzantine monasteries in Jerusalem and Palestine, reinforced the hypothesis about the elements of the byzantine hospital practice predominating in the foundation of the Hospital of Saint John in Jerusalem. In this sense, it has been noted that hospitals and hospices established by the franks in the Latin Kingdom were mainly appropriations of establishments that existed previously in the area since the byzantine era. ${ }^{33}$

The second historical factor that links the origin and deployment of the Hospital with Byzantium relates to the posterior history of the hospital. The links of the Latin Kingdom with the Greeck Empire increased thanks to the regular contact that the emperor Manuel Comneno I (1143-1180) kept with the rulers of the Frankish states. By this way, the direct influence of Byzantium increased in these cities. Such influence, as Anthony Luttrell pointed out, would have worked in the development of the Order in several aspects. According to the same author, it is also probable that this connection had had an effect on the functioning of the house of the brothers in

53/4 (1978): 728.

28. Miller, Timothy. "The Knights of St John...": 717.

29. Mitchell, Piers. D. Medicine in the Crusades...: 61.

30. For the amalfitanian foundation, see Riley-Smith, Jonathan. The Knights Hospitallers in the Levant, c. 1070-1309. Hampshire: Palgrave Macmillan, 2012: 34-35;On Amalfi and the first brothers, see also, Luttrell, Anthony. "The Earliest Hospitallers", Montjoie: Studies in Crusade history in honor of Hans Eberhard Mayer, Benjamin Kedar, Jonathan Riley-Smith, Rudolf Hiestand, eds. London: Variorum, 2007.

31. Miller, Timothy. "The Knights of St John...": 728.

32. “(...) the Amalfitans of the eleventh century were in contact with orthodox monasticism, since they had founded in the reign of John Tzimiskes (969-976) a monastery for their citizens on Mount Athos and -a little later organized a religious house in Constantinople itself". Miller, Timothy. "The Knights of St John...": 728.

33. Amouroux, Monique. "Colonization and creation of hospitals: the eastern extension of western hospitality in the eleventh and twelfth centuries". Mediterranean historical review, 14 (1999): 33; Touati, François-Olivier. "La Terre sainte: un laboratoire hospitalier au Moyen Âge?", Sozialgeschichte Mittelalterlicher Hospitäler, Neithard Bulst, Karl Heinz Spiess, eds. Ostfildern: Jan Thorbecke Verlag, 2007. 
Jerusalem and their hospital organization. ${ }^{34}$ The medical aspect of such connection will shape our analysis.

\section{Personnel organization of the hospital in Jerusalem}

The construction of the great buildings of the order of Saint John was finished during the first years of the decade of the sixty of the $12^{\text {th }}$ century. ${ }^{35}$ Among them was the palace of the master, three churches and their convent buildings, one bathroom, stables, services buildings and the hospital. ${ }^{36}$ This, built around the 1150 , replaced the hospices of the order dedicated to the lodging of pilgrims and the care of the sick. In any case, the built of the great hospital modified the charitable spirit expressed in the medical attention. In this sense, Rogers de Moulins in the statutes promulgated in 1182 called every brother of the different houses to serve the sick with the sentence that "by this work they will deserve the glory in heaven".${ }^{37}$ In the same way, the Anonymous Cleric pointed out,

Et 'sicut non est personarum acceptor Deus', cuiuscumque nacionis, cuiuscumque condicionisque et utriusque sexus infirmi recolliguntur in ista domo ut, Domini misericordia, quanto accumulatur multitudo languencium, tanto ibi augmentatur numerositas dominorum. Quin ymo, sane intelligens domus hec sancta quod omnes Dominus ad salutem invitans neminem vult perire, pagane professionis homines in ea etiam misericordiam inveniunt, sed et Iudei, si afluunt, ut pro quibus seipsum affligentibus oravit Dominus, dicens: 'Pater, ignosce illis, quia nesciunt quid faciunt'. ${ }^{38}$

Like in the first rule of the Order, the sicks are mentioned like the "lords" of the Hospital. ${ }^{39}$ At the same time, their atention is associated to the Christian charity, expressed in the fact of the reception of every person regardless the origin or religion.

\footnotetext{
34. Luttrell, Anthony. "The Hospitallers in Twelfth-Century Constantinople", The Experience of Crusading, Jonathan Riley-Smith, Marcus Bull, Norman Housley, Peter W. Edbury, Jonathan Phillips, eds. Cambridge: Cambridge University Press, 2003: 225-32, esp. 229. See also Miller, Timothy. “The Knights of St John and the hospitals of the Latin West". Speculum, 53/4 (1978): 709-733. This article received serious questions. On the problems with Miller's proposal, see Edgington, Susan. "Medical care in the Hospital...": 31-32.

35. See the plan of the hospital complex prepared by Conrad Schick from the archaeological evidence. Schik, Conrad. "The Muristan or the Site of the Hospital of St John at Jerusalem". Palestine Exploration Fund Quarterly Statement, 34 (1902): 42-56.

36. Probably, the number of people residing in the complex was 400 among all the members of the order, including the sergeants, waiters and general staff. Boas, Adrian. Archeology of the Military Orders. London: Routledge, 2006: 44.

37. Delaville-Le Roulx, Joseph, ed. Cartulaire Général...: 426 (doc. No. 627).

38. Beltjens, Alain, ed. "Le récit d'une journée au Grand Hôpital...": 39.

39. The "lords" are the sick themselves. Delaville-Le Roulx, Joseph, ed. Cartulaire Général...: 62-70 (doc. No. 70).
} 
We also know how the filantropic byzantine tradition was expressed in the creation of hospitals and different institutions for the poor and the sick. ${ }^{40}$ In the typikon of Kosmosoteira, his founder urged the brothers of this monastery to, above all things and without exception, do everything for the poor. ${ }^{41}$ In the same sense, John Comneno II stated for the Pantokrator that those weakned by the old age, those oppressed by the poverty, and the afflicted by different diseases should be received in the hospital. At the same time, it was stated that they should stay in the hospital until the recovery of their wounds or until they want. In addition, in the typikon of the Pantokrator it was added, as expressed in the statutes of the Hospital, that the attention to the poor and the sick was a way to intercede for sins committed by the man. ${ }^{42}$

Again, in the comparison of these passages is expressed the religious sense of the medical attention not only to the brothers of the monastery but also, and especially, to all the poor and peregrines. For this, the domus Dei of the order, as the bizantyne institutions, hired doctors and different professionals. This was extremly newfangled for the western world. In Europe, before the $13^{\text {th }}$ century, the brothers of the monasteries did not attend any person outsider from their own community of brothers. Neither would they pay for the care of people, a task that was understood as part of the charitable work. For the Anonymous Cleric, for example, this was in deed surprising.

Hoc tenore, hac pietate, hoc caritatis intuitu, beatum hospitale hinc practicantes theoricos, inde cyrugicos et minutores tenet stipendiarios. (...) O quam felix in hac sua institutione conventus, qua felicis Samaritani factus est imitator, qui de curandis proximis etiam in agone contendit. ${ }^{43}$

We should remark the discursive operation made by the author about the hiring of doctors by the hospital. He uses the parable of the Good Samaritan to highlight the charitable act of the brothers of Saint John attending the sick by hiring different professionals, i.e., he distinguishes the kindness of the Hospital and the importance of using money in order to require the service of physicians and others professionals.

Instead, in the byzantine hospitals this aspect was not novel. In the different documents regarding the medical care provided in these institutions, we observe

40. On the origin, maintenance and philantropical development of the hospital institutions of the byzantine world, see the classical studies of Demetrios Constantelos, Evangeline Patlagean and Judith Harris. Constantelos, Demetrios J. Byzantine philanthropy and social welfare. New Brunswick - New Jersey: Rutgers University Press, 1968; Patlagean, Evelyne. Pauvreté économique et pauvreté sociale à Byzance (IVeVIIe siècle). Paris: Mouton, 1977; Harris, Judith. "Ideals of charity, realities of welfare: The philanthropic activity of the Byzantine church", Church and people in Byzantium, Rosemary Morris, ed. Birmingham: University of Birmingham, 1986: 151-164. For the Comnenos period, see Jeanselme, Édouard; Oeconomos, Lysimachos. "Les œuvres d'assistance et les hôpitaux byzantins au siècle des Comnènes", I Congrès de l'Histoire de l'Art de Guérir. Anvers: Impr. De Vlijt, 1921: 231-259.

41. Patterson Sevcenko, Nancy, trans. "Kosmosoteira: Typikon'...": 837.

42. Jordan, Robert, trans. "Typikon of Emperor John II Komnenos...": 738.

43. Beltjens, Alain, ed. "Le récit d'une journée au Grand Hôpital...": 47-48. 
a strong hierarchical structure of professional employees, supervised by some brother in charge of the hospital of the monastery. ${ }^{44}$ In the case of the hospital of the Pantokrator, the staff was conformed by professional doctors. ${ }^{45}$ The general supervision of the hospital was in charge of two expert physicians (primikerioi). In every one of the five wards of this hospital, two doctors were assigned (protomenitai), besides three main assistants, two general assistants and two cleaning assistants. ${ }^{46}$ At the same time, the typikon indicates that four extra doctors had to be hired for the patients residing in the hospital. Two of them, had to be experts physicians and two, surgeons. ${ }^{47}$

This hierarchy of professionals is also reproduced in the hospital of the monastery of Kosmosoteira. In its typikon it was established that the superior brother had to hire one expert physician in fractures to attend the hospital residents. ${ }^{48}$ In the documents of the order in Jerusalem appears the same indication about hiring doctors and other professionals to care for the sick. For example, the statutes of 1182, stated that: (...) sil establi par l'assentiment des freres, que por les malades de l'Ospital de Jerusalem soient louez IIII mieges sages, qi sachent conoistre la qualité des orines et la diversité des malades, et lor puissent amenistrerremede de medicines. ${ }^{49}$

In the same way, the Administrative Regulations described that, Il est jugie et establi au chapistre general que $m$. et $v$. bezants soient donez au frere hospitalier qui a la cure des malades por louer mieges et por amandles as malades (...). ${ }^{50}$ While, in a more extensive passage, the Anonymous Cleric declared,

Sed quoniam inferioris phisice prorsus ignari nonnisi ceco casu plura degustantibus huismodi possunt exhibere temperamentum, sanctus hospitalis conventus theoricorum peritie fideli practicorum cure infirmos suos sancte commisit ac provide. (...) Propter ergo cum infame periculum evitandum, sunt enim in hospitali quatuor medici phisicam docti, ita domus stipendiarii, ut aliquam curam infirmis hospitalis alienam non presumant, qui et iuramento constringuntur quod nullius admonicione, plura nullius dissuasione, pauci-hora exspectent ab hospitali-queque ad salutem infirmorum suorum noverint necessaria, hinc in electuariis,

44. Jordan, Robert, trans. "Typikon of Emperor John II Komnenos...": 756-766; Patterson Sevcenko, Nancy, trad. "Kosmosoteira: Typikon'...": 830-831. About the byzantine physicians of the hospitals, see Miller, Timothy. "Byzantine physicians and their hospitals". Medicina Nei Secoli Arte E Scienza, 11/2 (1999): 323-335; Miller, Timothy. "Byzantine hospitals"...: 53-63. Also, Bennett, David. “Medical practice and manuscripts in Byzantium". Social history of medicine. 13/2 (2000): 279-291. Also, Bennett, David. Medicine and Pharmacy in Byzantine Hospitals. A study of the extant formularies. London-New York, Routledge, 2017.

45. Miller, Timothy. The birth of the hospital...: 12-29. On the social statues of byzantine physicians in the twelfth century, see Kazhdan, Alexander. "The image of the Medical doctor in Byzantine literature of the tenth to twelfth Centuries". Dumbarton Oaks Papers. 38 (1984): 43-51.

46. Jordan, Robert, trans. “Typikon of Emperor John II Komnenos...": 757.

47. Jordan, Robert, trans. “Typikon of Emperor John II Komnenos...": 758.

48. Patterson Sevcenko, Nancy, trans. “Kosmosoteira: Typikon'...": 830.

49. "It is established, in agreement with friars, that four physicians are contracted for the ill people of the Hospital of Jerusalem; these must know the condition of urine and the variety of diseases and be capable of bringing cure with medicines". Delaville-Le Roulx, Joseph, ed. Cartulaire Général...: 426 (doc. No. 627). 50. "it has been estimated and established in the General Chapter that 1500 bezants are given to the Hospital friar who is responsible for the ill people, in order to contract physicians and to buy fruits for the sick people (...)". Edgington, Susan. "Administrative Regulations...": 26. 
inde in aliis medicinis, quia de suo nulla egris medici subpeditant medicamenta, sed de domo illis ministrantur omnia. ${ }^{51}$

From this passagge we can conclude, in the first place, like in the statutes of Roger de Moulins, four "wise" doctors were to be hired -i.e. those who prescribed therapies and indicated what the rest of the professionals had to do. In the second place, like the Anonymous Cleric declared, there was a distinction between those "experts of lower physics", and the others, "responsable for the kind care". In the same way, in a letter of 1184 to Roger de Moulins, the pope Lucius III, in relation to the medical task of the Hospital, mentioned the presence of four medici and the same number of cyrurgici working in the Hospital. This proves the existence of a hierarchical distinction between one another. ${ }^{52}$

On the other hand, it is declared that the two groups of professionals were hired by the Hospital. The Anonymous Cleric adds that they were provided with all the necessary medicine. As it was said about the byzantine institutions, ${ }^{53}$ both the professionals and the supplies needed for the sick came from the house stipend.

Another coincidence comes from the fact that the Order hired professionals of lower rank. Indeed, there were servants designated for different tasks in the hospital. The Anonymous Cleric mentions the existence of surgeons and minutores, also employees of the hospital: Habent enim suos minutores infirmi, qui tenentur eos omni die, quecumque hor fuerit, minuere. ${ }^{54}$ On surgeons: (...) preter prefatos theoricos cyrugicos tenet stipendiaros, ut de sauciis curam habeant quotquot ad ipsum confugiunt. ${ }^{55}$

As we have previously mentioned, in the rule of the Pantokrator it is also established that, besides the physicians in charge of the wards, surgeons had to be hired. The hierarchical distinction in the Byzantine hospital is reinforced with the different stipends that each one would receive for their task. ${ }^{56}$ Like this institution, the Hospital of Saint John also had different clientes who did different tasks acting under the indications of the physicians. In the statutes of Rogers des Moulins it is mentioned the existence of nine sergeants assigned to wash the feet, change the sheets, feed the poor and be at the service of the sick. ${ }^{57}$

In the same way, the typikon of the Kosmosoteira indicates that for the hospital, had to hire eight servants to care for the sick. ${ }^{58}$ The typikon of the Pantokrator disposed nursing staff, ${ }^{59}$ cleaning assistants, cookers, and others. ${ }^{60}$ It also indicated how the distribution of the staff in each wards had to be. For the Hospital of Saint John,

51. Beltjens, Alain, ed. "Le récit d'une journée au Grand Hôpital...": 45-46.

52. Delaville-Le Roulx, Joseph, ed. Cartulaire Général...: 458 (doc. No. 690).

53. Jordan, Robert, trans. “Typikon of Emperor John II Komnenos...": 758.

54. Beltjens, Alain, ed. "Le récit d'une journée au Grand Hôpital...": 46.

55. Beltjens, Alain, ed. "Le récit d'une journée au Grand Hôpital...": 47.

56. Jordan, Robert, trans. “Typikon of Emperor John II Komnenos...": 762-764.

57. Delaville-Le Roulx, Joseph, ed. Cartulaire Général...: 425-429 (doc. No. 627).

58. Patterson Sevcenko, Nancy, trans. “Kosmosoteira: Typikon'...": 831.

59. Jordan, Robert, trans. “Typikon of Emperor John II Komnenos...": 758.

60. Jordan, Robert, trans. “Typikon of Emperor John II Komnenos...": 759. 
the Anonymous Cleric described how the routine of the hired doctors and other members of the personnel under their direction was.

Distribuuntur medici per vicos ut quisque discreta sciat congnicione quos habeat infirmos curare, ne unius vici respectu alterius tediosam multitudinem alter eorum propter alterum aspernaretur, vel ne confus a commixtione in vicum eundem assidue concurrerent, et aliqua alterna fiducia die aliquo sine cura preterirent. Omni autem die in mane et vespere suos tenentur infirmos visitare, urinas, pulsus qualitates iuxta tenorem artis sue attendere. Cum autem ad visitandos infirmos accedunt, secum quisque illorum duos assumit clientes de vico quem est perambulaturus et primo perambulato alios duos resumit de alio et sic deinceps, ut unus syropum, oximel, electuaria et alias medicinas egris conferentes portet, alter urinas ostendat, iudicatas abiciat, urinalia emundet, quam cui dietam medicus iniungat similiter cum servo suo diligenter intelligat, minutorem ad infirmos suos vel etiam infirmos ad minutorem adducat. ${ }^{61}$

As we can see, the medical organization is the same as that of the byzantine hospital. There is a wise doctor, whose task is to go through the wards, see the condition of the sick and indicate the right therapies for each. As we have seen, the rule of the Pantokrator also indicated that for each ward two special doctors had to be appointed, together with a body of assistants.

According to our comparison, it is also interesting, the role of the primikerioi like general supervisor of the medical work of the hospital of the Pantokrator. His function consisted of controlling the performance of the doctors and the treatment given to the patients. ${ }^{62}$ The Anonymous Cleric established the same for the hospital in Jerusalem, Omnibus enim tam magistris vicorum quam clientibus suis ac medicis unus fratrum superponitur, qui quasi antonomastice hospitalarius in domo sua illa nuncupatur. Although the latter is a brother of the order, and the Byzantine employee is part of the hired staff, in both cases, it is about a person in charge of supervising the work of the doctors and assistants with them.

\section{Hospital wards and services provided to the sick}

The rule of the Pantokrator indicated the disposition of 50 beds for the attention of the sick. These were divided in five wards with different quantities of them. The first of these wards, with ten beds, was for patients with fractures and wounds. In another ward, for patients with ophthalmological and intestinal diseases, there were eight beds. In a third ward, for women, there were 12 beds. For this ward, the typikon also established that there had to be two doctors, together with a female

61. Beltjens, Alain, ed. "Le récit d'une journée au Grand Hôpital...": 45-46.

62. Jordan, Robert, trans. “Typikon of Emperor John II Komnenos...": 758. 
doctor and eight female assistants. ${ }^{63}$ The remaining beds were divided into the other two wards and were for patients with moderate ailments. ${ }^{64}$

In the same way, the Jerusalem hospital was also divided in different wards. The Anonimous Cleric mentioned eleven. Among these, some special wards were for women. ${ }^{65}$ The description made by the peregrine John of Würzburg, proves that persons of both sexes received attention in the hospital in the same way.

Iuxta aecclesiam Sancti Sepulcri (...) ex opossito versus meridiem est pulchra aecclesia in honore sancti Ihoannis Baptistae constructa, cui adiunctum est hospitale, in quo per diversas mansiones maxima multitudo infirmorum tam mulierum quam virorum colligitur, fovetur et maxima expensa cotidie reficitur, quorum summam tunc temporis cum essem presens ab ipsis servitoribus hoc referentibus ad duo milla languentium fuisse cognovi, ex quibus aliquando infra noctem et diem plusquam quinquaginta mortui exportantur, iterum atque iterum pluribus de novo accedentibus. ${ }^{66}$

Similarly, the hospital of the Pantokrator and the domus Dei of the Hospitallers kept important similarities as regards the services given to the sick. In this sense, in the statutes of Roger de Moulins it was established that the beds for the sick had to be comfortable and wide, and had their own blankets and sheets. ${ }^{67}$

The rule of the byzantine monastery stated that each one of the beds had a mattress, a blanket and a pillow. For the winter, two blankets made of wool of lamb. ${ }^{68}$ Like this, the Administrative Regulations for the hospital in Jerusalem, declared that, Alentree dyver baille len a chascun malade i. paire de soliers, et par tout yver covertors et carpites tant come mestier est. ${ }^{69}$

In the typikon of the Pantokrator it was also indicated a continuous supply of blanckets and clothes for the poor and the sick. Besides, the typikon indicated that the clothes of the sick, be washed and put in care until the moment of their departure. It also indicated that the bedclothes should be changed with some regularity and that the clothes left over should be kept, because they could be distributed among the poor. ${ }^{70}$ The rule of the Kosmosoteira expresed in a similar way the distribution of these services. ${ }^{71}$

About the hospital in Jerusalem, the Anonymous Cleric mentioned,

63. Jordan, Robert, trans. “Typikon of Emperor John II Komnenos...”: 757.

64. Jordan, Robert, trans. “Typikon of Emperor John II Komnenos...": 757.

65. Beltjens, Alain, ed. "Le récit d'une journée au Grand Hôpital...": 41.

66. Theodoricus. Peregrinationes tres; Saewulf, John of Wurzburg, Theodericus, ed. Robert Huygens. Turnhout: Brepols Publishers, 1994: 131.

67. Delaville-Le Roulx, Joseph, ed. Cartulaire Général...: 426 (doc. No. 627).

68. Jordan, Robert, trans. “Typikon of Emperor John II Komnenos...": 757.

69. "At the beginning of winter there shall be handed to each patient 1 pair of slippers, and all winter covers and rugs, as many as are needed". Edgington, Susan. "Administrative Regulations...": 30.

70. Jordan, Robert, trans. “Typikon of Emperor John II Komnenos...": 757.

71. Patterson Sevcenko, Nancy, trans. “Kosmosoteira: Typikon'...": 831. 
In palacium vero producti, super culcitras plumarias in lectis tornatilibus cubantur; ne vel algore pavimenti vel ex duricia contristentur, albis interponuntur linteaminibus, culcitris consutilibus et aliis villosis coopertoriis superpositis; ne vel aliorum pannorum ledantur asperitate, constringantur vel frigore, pallia eis traduntur de domo, et sine pellibus et pellicii vel pelles, quibus induantur cum ad deserviendum nature surrexerint, sed et setulares ne vel immundicia pedibus surgentium adherat vel ne vel marmoreum frigus nocivum plantis subsistat. ${ }^{72}$

This description has many coincidences with the one established in the statutes of Roger des Moulins ${ }^{73}$ and the indications of the Administrative Regulations. ${ }^{74}$ This last document describes also how the admission of a new patient was. It began with the confession of his sins before the chaplain. Then, the bed of the patient was prepared and the Hospitallers gave him the utensils for eating and drinking. The rule of the Kosmosoteira also established that after being admitted, all the sick should be provided with one cup and a plate for their exclusive use in the hospital. ${ }^{75}$

On the other hand, and as we have already mentioned, in the Administrative Regulations, in the statutes and in the description of the Anonymous Cleric the disposition of clientes, or sergeants, who work in the different wards of the hospital in Jerusalem, was stated.

Sed quia quasi humane imbecillitati est innatum unum solum hominem tot diversis tante multitudinis administracionibus non posse sufficere, singulis fratribus, qui singulis presuntvicis, duodecim clientes admittuntur suffraganei; quot sunt vici, tot sunt fratres super eos magistri et tot clientum. ${ }^{76}$

Their functions included, cleaning and dressing the patients, taking them to the bathrooms - for those who could not do it by themselves-, providing them with fresh water and make their beds. ${ }^{77}$ The rule of the Pantokrator also indicated the importance of bathing the patients and transporting them to the bathroom if they could not do it by themselves. ${ }^{78}$

Last, both the Hospital of Saint John ${ }^{79}$ and the byzantine institution ${ }^{80}$ had a night service for the sick. As the Anonymus Cleric describes,

Sed quasi adiuncticulo ad sepedictos infirmorum clientes redeamus. Quibus propter egros suos sedulo custodiendos nocturna deputatur vigilia, in omni vico contubernalis vicissitudine per

72. Beltjens, Alain, ed. “Le récit d'une journée au Grand Hôpital...": 40-41.

73. Delaville-Le Roulx, Joseph, ed. Cartulaire Général...: 426 (doc. No. 627).

74. Edgington, Susan. "Administrative Regulations...": 30.

75. Patterson Sevcenko, Nancy, trans. “Kosmosoteira: Typikon'...": 831.

76. Beltjens, Alain, ed. "Le récit d'une journée au Grand Hôpital...": 41-42.

77. Edgington, Susan. “Administrative Regulations...": 24-26.

78. Jordan, Robert, trans. "Typikon of Emperor John II Komnenos...": 760.

79. Edgington, Susan. "Administrative Regulations...": 24, 26.

80. Jordan, Robert, trans. “Typikon of Emperor John II Komnenos...": 757. 
binarium alternata. Ipsis etiam incumbit lampades accendere, que more solito ante infirmos consueverunt ardere a crepusculo donec rucilante aurora nostri superficiem hemisphaerii sol ortus sui splendore irradiaverit. (...). Ministri siquidem ad vigilandum per singulos vicos contuberniati tenentur infirmos suos deambulacione assidua visitare, ut in sompnis denudatos cooperiant, male iacentes conponant, sacerdotes districtos adducant, mortuos in monasterium deferant, debilibus in quibuscumque molestiis subveniant, sicientes potent. ${ }^{81}$

He also added,

(...) ne duos servos humilis conventus solis relinquat mercenariis per nocturni tranquillitatem silencii custodiendos, mox finito completorio piam per omnes vicos tocius palacii egrorum acomodabilem facit processionem, quo fratrum previo cum lucerna, reliquo cum candela, ut convenienter videant fratres, si aliquid incompositum, aliquid indecens, si aliquid illic pietati apparuerit inimicum. Et si contumelia, que semper angarioso tumultu misericordie ac pacis unioni novercatur, partes suas inibi ausu temerario intercalaverit, illorum assensu fit emendatum. ${ }^{82}$

As we can see, the Hospital and the Byzantine institution both had personnel for the surveillance of the sick during the night. If we look at the description of the second passage of the Anonymous Clergy, we note that, in addition to the two clientes, two brothers of the convent were also responsible for monitoring the condition of the sick at night. Exactly like in the rule of the Pantokrator. ${ }^{83}$

\section{Conclusions}

We point out the difficulties of the studies that tried to determine the origin of the hospital model of the Hospital of San Juan from the comparison of the prescription of diets in different medieval medical treaties with the one ordered by the Hospitallers. We also indicate how the coincidences in the type of meals presented in more than one document of the order of the Hospital with different texts circulating in the region loses its meaning. In this sense, from our comparison with two of the great Byzantine hospitals, we observed that the hospital of the Knights of Saint John received more than one element from the Greek hospital culture.

In fact, this culture was the model on which the brothers of Saint John relied when they built their hospital and the efficient system of medical care and social assistance. The existence of different wards according to sex, the wide availability of beds, the assistance to women in labor, different medical professionals and a hierarchical structure that organized their work, are some of the elements which allow us to declare that the model of the Byzantine medical-hospital culture was the basis of the emblematic institution for sick in the Latin Kingdom of Jerusalem.

81. Beltjens, Alain, ed. "Le récit d'une journée au Grand Hôpital...": 49.

82. Beltjens, Alain, ed. "Le récit d'une journée au Grand Hôpital...": 50-51.

83. Jordan, Robert, trans. “Typikon of Emperor John II Komnenos...": 758. 